Franz J. Hinkelammert

\title{
CHANGES IN THE RELATIONSHIPS BETWEEN THIRD WORLD COUNTRIES AND FIRST WORLD COUNTRIES*
}

I wish to develop some theses on the changes in the relationship between Third World countries and First World countries, which have been strongly affected by the crisis of socialism in the Soviet Union and in the Eastern European countries. It is a profound change, which came about in the ' 80 s but which had already been developing in the decades prior to that.

\section{First Thesis}

I believe, and this will be my first thesis, that in recent years there has been a transformation in world capitalism, which came to light at the most dramatic moment of the crisis of socialism, that is to say, with the fall of the Berlin wall in November 1989. I was at that moment in the Federal Republic of Germany and I could see a strong symbolic connection between the fall of the wall and the massacre of the Jesuit community in San Salvador, which took place only a week later. What specially struck me was that the European media concentrated almost exclusively on the fall of the wall, while the other event, which showed so clearly what the Third World had become, was reduced to some marginal news items on the radio and in a few newspapers. What had happened in San Salvador was an "extermination" in the classic style of totalitarianism of the '30s, when one of the liberation theology centres of the western world was "eliminated." The western media reacted as the media of the totalitarianisms of the ' 30 s had reacted. The government of the USA, through the FBI, kidnapped the most important witness and obliged her, through threats, to change her testimony. Consequently the other western governments also collaborated to cover up this fact. ${ }^{1}$ One month later the military invasion of Panama took place, with the approval of all western societies. There was also little or no news about this event.

The control of the media was once more brought about by the classic methods of the totalitarianism of the '30s. On the aftemoon of the first day of the invasion a Spanish reporter from Spain's newspaper El País was killed, which was a sufficient warning to all the members of the media who were there at the time.

\footnotetext{
* This paper was published in the journal Voices from the Third World, June 1993. Reproduced here by courtesy of the author.
} 
There isn't necessarily a connection between the two events - the fall of the Berlin wall and the Jesuits' massacre in San Salvador - though one cannot help wondering at the timing. Few historical moments in recent years have been as propitious for the massacre which took place in San Salvador as this one was. But even if there is no connection, there is no doubt an undeniably symbolic relationship exists between the two. This proves to us that a capitalism which tried to appear, between the ' 50 s and '70s, as a capitalism with a human face, needs no longer try to do so. It can now once again appear as a capitalism without a human face.

Capitalism today feels it can say "We have won." A philosophy of the State Department of the US government emerges, which talks of the end of history (and, relating it to Hegel, of the reality of the absolute idea) and which promises a future in which there is no longer any history or essential conflict, and in which the First World has found its peace and the Third World is no longer relevant. ${ }^{2}$

The world which now appears and announces itself is a world where there is only "one lord" and "master," and where there is only one system. We have a world with only one empire which extends everywhere; this empire covers and includes the whole world. It suddenly becomes clear that there is no place of asylum. With only one empire there cannot be any refuge. The empire is everywhere. It has total power and it knows it. Everywhere the empire announces that it has all the power. The self-proclaimed "open society" constitutes the first closed society, from which there is no escape to the outside.

This means that for the first time the Third World finds itself completely alone. In its conflict with the First World of central capitalistic countries, it can count on the support of no other country. It can no longer resort to any Second World which in some way could be in solidarity with it. To the degree in which the Second World of the socialist countries continues to exist, it no longer offers any solidarity to the Third World, and has become part of the North confronting the South. It has been said in many parts of Latin America that the Second World cannot prosper, if it is not admitted by the First World to that banquet where the Third World is devoured.

Together with all this there is a deeper conviction whose importance is undeniable, and that is that the consciousness of an alternative is lost. It seems there are no longer any alternatives, and the "Totality" which is how the First World proclaims itself, is the expression of this state of consciousness. We are a world which is the Absolute Idea! When Kolakowski confronted Stalinism in the '50s he criticised it for being a blackmail with only "one alternative" $(!)^{3}$ 
However, he couldn't imagine what happens when this blackmail with only one alternative is put into effect and executed by a world system which has absolute worldwide power. Actually, we have arrived at a situation in which blackmail with only one alternative can be brought about without restrictions. Today this blackmail has been imposed on the whole world.

The crisis of socialism did not only take away from the Third World the possibility to seek solidarity in its conflict with the First World. It now can no longer resort to socialism as it seeks alternatives. It can now no longer use socialism to demonstrate that there really is an alternative, however imperfect it may be. It can now no longer say that there is an alternative which can be improved and has a future; it can no longer say that it is possible to have another future, to have in the future something that is different from the present.

Capitalism in the '50s and '60s was a capitalism of social and economic reforms which was also concerned with the development of Third World countries so as not to allow alternative movements to flourish. But this capitalism believes that today there is no alternative, whatever it does. Therefore it again becomes wild capitalism - capitalism without a human face.

Most of us know that we are on a roller-coaster heading for the abyss. However, capitalism does not even try to put the brakes on. It says to us, "Do you have an alternative?" At the same time it continues to do all it can to prevent an alternative to this death trap from being found.

This is our first thesis: the crisis of socialism has extremely weakened the Third World, but at the same time has weakened the possibilities of survival for humanity itself.

\section{Second Thesis}

This phenomenon of the weakening of the Third World is complemented by another which we could discuss starting with the following question: Does the First World still need the Third World?

We know that the production structures of the Third World have developed on the basis of its labour force, used in the production and exportation of its raw materials. The importance of the Third World has consisted in the development of its raw materials produced by the existing labour force. Where there wasn't enough labour force, the First World obtained it through 
forced slave labour. These raw materials were the basis of the development of today's developed countries.

Without a doubt, today we experience certain trends towards the loss of importance of the production of raw materials of the Third World. Many "natural" raw materials are substituted by "synthetic" raw materials, which also makes the labour force which produced them redundant. Many raw materials are still produced in the Third World but it becomes more and more difficult to use all the available labour force in their production.

This results in a restructuring of the Third World. From a world in which raw materials were exploited by exploiting the existing labour force, it has become a world where the population itself has been made redundant. Differently to what happened up to 100 years ago, the most important aspect in relation to the population of the Third World today is that it is a redundant population from the point of view of the First World and its economic needs. The Third World is still needed - its seas, its air, its nature, even if only as a garbage dump for the First World's poisonous garbage. Its raw materials are still needed as well. In spite of some raw materials losing their importance, the Third World continues to be of vital importance for the development of the First World. What is no longer needed is the greater part of the population of the Third World.

This is the reason why the First World does not withdraw from the Third World but now develops an image of it as a world where there is an excess of population. This redundant population, which is referred to in terms of population explosion, is seen as dangerous and no longer as something to be exploited. Actually technical development today is such that it cannot exploit this population. The structure of capitalism is such that it can no longer exploit the world's population. However, it considers population which it can no longer exploit as redundant. It is a population which is seen as overpopulation and which should not even exist but it is nevertheless there. This capitalism has nothing to do with the fate of that population.

The concept of exploitation now changes. As we know, the classic concept of exploitation refers to an available labour force which is effectively used in production and from which is taken the product it makes. We are referring to the concept of surplus exploitation as it was developed in the Marxist tradition. However, there now arises a situation in which a population no longer can be used for capitalistic production and where there is no intention of using it, or any possibility of doing so in the future. A world emerges where to be exploited becomes a privilege. 
To be precise, this concept of exploitation appeared at the beginning of the 19th century in Europe. That was a world in which, during periods of great economic activity, there was full employment for the labour force and therefore when activity slowed down the workers alternated between employment and unemployment. But, in present-day capitalism, this situation has changed. There is a situation where growing segments of the population of the Third World are no longer "exploited" in this sense. The more the population appears to be redundant, the less this concept of exploitation exists. This is why it has become less important. This is also observed in the conscience of the worker himself. He feels less and less he is exploited when he realises that he is privileged compared to all those who are redundant. The whole relationship with exploitation then changes. This happens just as much in the industrialised world although it is much more extreme in the Third World.

This also means that the redundant population of the Third World has no power at all. Those who are redundant cannot go on strike, they have no bargaining power, cannot threaten. The proud saying of the 19th century worker, "All wheels stop if your strong hand desires it" can no longer be spoken by the population of the Third World, even though it did seem possible during the oil crisis. However it happened in a few specific countries and in exceptional conditions, at an also exceptional moment. The same can be said of the slogan "Proletariat of the world, unite." This was the cry of groups who felt they had the bargaining power which arose out of unity. Today this theme also is in a state of collapse. The peoples of the Third World have such a minimum bargaining power that they cannot demand their participation. The situation of the redundant population has become a situation in which their very existence is threatened.

This is the second thesis: the rich First World countries continue to need the Third World countries, but no longer need this population.

\section{Third Thesis}

In this situation the Third World countries lose the capacity to carry out any development policy. In the present situation, the only possibility of development of Third World countries is in the development related to the world market, which really means related to the market of the industrialised countries. This relationship is restricted to the production of raw materials. Although these become less important, there is nevertheless an ever growing competition among the Third World countries for these limited markets. The 
result is a drop in prices. With exports being greater in quantity, the availability of foreign currency becomes blocked or diminishes. Therefore, based on this traditional structure of production, development of Latin American and other Third World countries in general daily becomes less possible. For development, which would include the existing population, to be possible it would have to be based on the rapid growth of industrial production which would be integrated in the world division of labour.

There is clear evidence that the rich countries do not accept this type of development. We can see the systematic destruction of all the steps that lead to it. In spite of a few small countries managing to escape this fate imposed by the rich countries, the evident tendency of the Third World is towards destruction or slowdown of the industries which appeared between the ' 50 s and $70 \mathrm{~s}$. The rich countries do not expect any advantages to come out of the development of the Third World, only disadvantages.

The more environmental issues enter these considerations, the worse the situation becomes. It is known that sensible development of the Third World can no longer be a replica of the development of the presently developed countries. The environment would not be able to stand it. It is also known that a sustainable development would oblige the First World to change all its production structures and its technical decisions in order to make them adequate to the conditions for survival of the whole of humanity within the framework of nature as it exists today. Since there is no will to do this, the First World prepares itself to use the destruction of the Third World environment for its own gain in order to guarantee its own survival for as long as possible. We are faced with a "heroism" of collective suicide.

Here lies the importance of the Third World's foreign debt, which allows the First World countries to control the development possibilities of the Third World countries with a view to obstructing their success. This debt has become the decisive tool with which to dictate economic and development policy to the countries which are in debt. If we were to observe the trends of the imposed "structural adjustments," we would see that, obviously, the central conditioning consists in obstructing the energy, through industrial products, of the underdeveloped countries into the world division of labour.

The Third World's foreign debt is an ideal tool with which to attain this objective. The development of the Third World is suppressed in the name of goals which, directly and apparently, have nothing to do with it. The objective becomes invisible. What is visible is the debt these countries have, and their obligation to pay it. However, the result is that the Third World countries are 
reduced to a desperate production of raw materials which suppresses its potential for industrial development.

If one wants to explain this policy in a few words which would express what today dominates the First World like a phobia, one could say: Japan never again! Japan happened once, but will never again happen! Or do we seriously believe that we are prepared to accept a Japan as large as Brazil or India?

This is our third thesis: the rich capitalistic countries have lost interest in a development policy for the Third World and have opted to block it as much as they can.

Consequently, we have three theses:

1) Capitalism once again becomes wild capitalism; it no longer fears that alternatives are possible and therefore does not want to compromise.

2) The Third World is economically necessary for the rich countries but its population is not needed.

3) The rich countries consider development based on industrial integration in the world market as a threat; the foreign debt of the Third World works as an instrument to regulate, control and eventually block this type of development.

\section{The Search for Alternatives}

As we view the situation described in the above three theses, and which has no apparent solution, it is necessary to reflect on the possible alternatives. It must be frankly admitted that we still have no thought-out alternative. But this should not be an obstacle to start in our own way. It is necessary to start gathering the rough materials now. I want to propose an important element in this process of building a new alternative. It is the need to create ties between the poor and the excluded themselves, to strengthen the unity between groups and institutions in the First World and the Third World, and to think of a new model of development. The soul of this model of a new alternative should be solidarity, understood in a different way than it was experienced in the past.

At present there is a type of solidarity emerging which is different from the workers' solidarity in the 19th century. Workers' solidarity was the foundation of the power of the workers themselves, which was the result of their 
unity. That is why it was able to be essentially solid, so as to confront capital, which was a destructive force. The solidarity of a population reduced to a redundant population cannot now have this characteristic. It does not constitute bargaining power. However, it is, like workers' solidarity also was, a solidarity of mutual help. Nevertheless, for the last decade or two it does not constitute power anymore. It is the solidarity of the poor, not of the proletariat.

It can constitute power only to the degree in which there is solidarity of groups which are integrated in the society, with those who are excluded. It cannot limit itself to being the solidarity of a group that struggles, but it must be a human solidarity beyond any group, which includes the excluded as a basic condition. We are talking of the solidarity of the preferential option for the poor.

The trends of present-day capitalism, as we have seen, do not only develop the denial of solidarity, but the denial of the very possibility of solidarity as well. Solidarity today presupposes confronting this capitalism with the need for a just society which is participative and ecologically sustainable. Solidarity today will simply be a dream if it does not put into action this alternative to present-day capitalism and its destructive tendencies. However, capitalism denies it, as it also denies the possibility of this alternative, the very possibility of human solidarity. As it struggles to the death against all possible alternatives, it struggles to the death against the possibility of solidarity itself. It declares it to be an illusion, a bad habit, because if all alternatives are illusory, then solidarity is as well. It then persecutes the very intention of being in solidarity as something that is either ignorant or criminal. Solidarity is persecuted as a destructive "utopia."

Present-day bourgeois thinking transforms solidarity into something diabolical. To the degree in which their solidarity expresses what in Christian tradition is love of neighbour, it now considers that very preaching of love as diabolical preaching, a demonic temptation. ${ }^{4}$

This carries with it the extreme denial of any human dignity. Since solidarity and the love of neighbour are proclaimed as diabolical, the recovery of human dignity is diabolical as well. For bourgeois society, even Jesus himself is now transformed into the devil, which needs to be fought.

Human dignity is denied when solidarity is denied. This is not a simple declaration of abstract principles, but a very real matter. Human dignity is based on the possibility of living with dignity. The acknowledgement of this is necessarily the acknowledgement of the right to live with dignity. This means to eat, to have a home, education, health, and so on. If there is no 
acknowledgement of this as a human right, there is no possible acknowledgement of human dignity.

However, the aim to live with dignity is a possible alternative only if an alternative exists. If I deny the possibility of any alternative, I deny the person the possibility of being able to live with dignity. Thus I deny the person his or her dignity in every concrete way - and I transform human dignity into an abstract principle, with no content. It is clear that human beings who have been made redundant and who consequently consider themselves redundant no longer have human dignity; thousands of declarations will not alter this fact. The exploited are violated in their human dignity, but the redundant are not even given a dignity that can be violated. And here it is clear why in the western world the remarkable name "Cancer" is used to describe all liberation movements. I cannot recall one single liberation movement which was not called a cancer in Washington or in Europe, a cancer which must be cut out. This is the way the bourgeois world relates to liberation movements. The last time a cancer was mentioned in Latin America was in reference to Nicaragua and the Frente Sandinista. But it was also used in the case of Libya and Chile, and before that, I believe it was used for the first time in Indonesia in 1965. The word cancer replaced a word that was key to the Nazis, "parasites." This word was in reference to the same phenomenon. Substituted by the word cancer, it is today ever-present in the repression of the liberation movements in the Third World and, beyond those, in the repression of any form of dissidence.

If one were to take seriously this relationship between the existence of alternatives and human dignity, one would also see that the struggle of the bourgeoisie against any alternative, in order to destroy it, is also a struggle for the destruction of human dignity itself. People are not given the right to live with dignity. They can live, and live well, if they are able to find the space in the market to do so. If they do not achieve it, the market proves that they also don't have human dignity nor the right to claim it. Therefore in the process of the destruction of alternatives, and in the production of redundant people, attempts are made to destroy the very meaning of human dignity to such a degree that these human beings who are made redundant see themselves as redundant. I believe that the whole ideological struggle today revolves around this. This is the content of psychological war. I also believe that the crisis of socialism has made it possible to really achieve this denial of human dignity.

This is not true exclusively in the "production of redundant people" in the Third World. A similar process is occurring in the First World, although 
at a lower level. Deep down, the psychological war, which at least in the Third World is widespread, tries to convince people who are made redundant that they indeed are redundant, and consequently they destroy each other instead of being in solidarity among themselves. I think the first author to really understand this process and describe it was Nietzsche. It is surprising to what degree he understood that people who are made redundant have to see themselves as such in order to destroy their very own selves and one another. ${ }^{5}$

Situations such as these are found today in many societies in Latin America: in the Dominican Republic, Honduras, Colombia, Peru, Argentina and others.

These processes show that to be in solidarity today is different to what it was in previous times, and there is no doubt that it has become once again of great importance. It is not simply a question of a call to unite and help. It requires the total restoration of human dignity which has been denied at its very roots. It must be made clear that the denial of alternatives is the denial of human dignity, and we insist on that dignity.

It does not mean we have the alternatives already worked out and up our sleeves. Is the genocide in the Third World legitimate if the victim-population does not dispose of the means to develop an alternative for the Third World and First World countries? If at present we do not have a developed alternative to the destruction of the Amazon or the Himalayas, is this destruction legitimate? We know that this destruction of humanity and of nature must end, and everyone has a duty to find alternatives. Capitalism is embarking on the collective suicide of the whole of humankind. Can it be that it is legitimate only because nobody has found an alternative? An alternative needs to be developed.

Many proposals for alternatives have been broken. However, I can see no reason for the victory which the bourgeoisie celebrates today. Every broken alternative is a loss of hope in being able to escape from the collective suicide which the bourgeois society is planning. Alternatives are not developed quickly in a congress or in a secluded office. It will become ever more difficult to develop alternatives because any alternative must include technical considerations which cannot be developed superficially. However, the bourgeoisie has monopolised the very technical capacity required to develop them.

What we must prove is that there will be no human survival if alternatives to the system which so obstreperously seems to be triumphing are not found. The alternatives cannot emerge unless the whole world's population de- 
mands them, because they know that they need them. Alternatives are not produced like sausages, to be offered later. There has to be an awareness that without them we are lost. Only thus will they be found. We will never have an alternative in recipe form because the alternative can only emerge when humanity realises that it needs it.

In spite of this, the basic elements for this alternative are known. We are talking of a new economic and financial world order, an order for the marketing of raw materials. We are also talking of the re-establishment of an economic policy in relation to labour and the distribution of income; a universal policy of education and health and the establishment of an ecological order which would channel markets so that economic growth would respect nature's reproduction. However, an alternative can only come from this if it is effectively embraced by the whole of society in order to put it into practice in its daily exercise of power.

At the moment it cannot be an alternative for one class only. We are talking of an alternative for all humanity. But the search for it, and the insistence on it, continue to be a class problem. This is a class struggle above which hangs the denial of an alternative. The bourgeoisie no longer has an adversary grouped into a class. Nevertheless, it continues to be the dominant class which acts as in a class struggle, in spite of this coming only from above. This position of the bourgeoisie needs to be destroyed in order to be able to discuss and act clearly. If the bourgeoisie does not give in in this class struggle, there will be no alternative. It has the power to destroy anybody and today there is no way to defeat it by means of a response on the level of this very same class struggle. If it does not give in, we will go to the abyss.

There only remains the resistance to lead our society to a re-structuring of itself. I would like to end with a few words spoken by Mark Edelman, one of the leaders of the Warsaw Uprising in 1944, "It is better to do something than to do nothing." This something is what we must do.

\section{Notes}

1 The media in western democracies actually spoke more of the writer Rushdie. He had been threatened with death in Teheran. Living in London, he received Mrs. Thatcher's protection and he survived. At the same time, that is to say during several months in 1989 , there was a press campaign in El Salvador which threatened the life of the Jesuits. They however continued in El Salvador under much heavier threats. The news agencies of the western democracies are as well represented in El Salvador as in Teheran. But they hardly spoke up. They did not do it after the massacre either, and yet they continued to speak of 
Rushdie who was already quite safe. Margaret Thatcher also showed practically no interest in the Jesuits. In Latin America there are many Rushdies; but they never have any protection. They are killed, and no western democracy bothers. The well-known French philosopher Glucksmann, who was awarded the peace prize by German booksellers, in his "laudatio" for Havel spoke of three heroes in the struggle against totalitarianism in 1989: Solzhenitzyn, Rushdie and Havel (See Friedenspreis des Deutschen Buchhandels 1989, Vaclav Havel, Ansprachen aus Anlaß der Verleihung, Frankfurt a. M. 1989, pp. 35-36).

However, these "heroes" whom I respect, are all alive today. Those who struggled for freedom in Latin America and the Third World, however, are murdered. They were killed by the western democracies in El Salvador, Brazil, Colombia, Venezuela, Honduras, which can count on the indiscriminate support of the western democracies of Europe and the United States. The massacre of the Jesuits is only one of many cases. Are they not the real heroes of the struggle against totalitarianism in 1989? Western democracies proclaim and at the same time celebrate their peace prizes, without even mentioning the war that they themselves are bringing about.

Glucksmann said: "Take a good look: in the year 1989 the end of this century is being announced" (36). Is it not the massacre in San Salvador that warns us of things to come?

2 See: Fukuyama, Francis, The End of Histony?, in: The National Interest, Summer, October 1989. See: Gallardo, Helio, Francis Fukuyama y el triunfo del capitalismo burgués. El final de la historia oel deseo de finalizar el serhumano?, in: Pasos, DEI, San José, 1990, No. 27. Also: Gallardo, Helio, Francis Fukuyama: el final de la historia y el Tercer Mundo, in: Pasos, 1990, No. 28.

${ }^{3}$ Kolakowski, El hombre sin alternativn, 1956. Unfortunately, he did not speak of the problem again after he moved to England. He no longer says that he again lives in a society without an alternative.

${ }^{4}$ Popper puts it like this: We are all quite sure that nobody will be miserable in the beautiful and perfect community of our dreams, and there is also no doubt that it would not be difficult to bring heaven down on earth if we loved one another. But ... the attempt to bring heaven on earth invariably produces hell as a result. It causes intolerance, religious wars and the saving of souls by means of the Inquisition (Popper, Karl, Ln sociedad abiertn y sus enemigos, Paidos Studio, Buenos Aires, 1981, Tomo II, cap. XIV, p. 403).

${ }^{5}$ Nietzsche, Friedrich, La voluntad de poderio, EDAF, Madrid, 1981, No. 55, p. 60. 